\title{
Staring into the Abyss of Time
}

BENEATH THE ROCK, MORE ROCK. It stretches deep into the earth in layered deposits of sandstone and shale, whose limits extend far beyond the edges of the plate. The engraving of the Harz Mountains shown in figure 1 (left), first published in 1785, depicts the textured surface of a quarry face recessed within a grassy landscape. To the right, a single figure ascends a hill toward a built enclosure. To the left, the curtain of the earth's surface has been cut away to reveal a hypothetical cross section of its unseen depths. The composition symmetrically divides the realm of the human from that of the geological, with the quarry in the center acting as a fitting intermediary; it is, after all, a site where matter is "unearthed" by human labor and converted into resources. But within a few decades of this print's publication, the preferred geological illustration of choice looked rather different, as an early example of a "stratigraphic diagram" found in Georges Cuvier and Alexandre Brongniart's Essai sur la géographie minéralogique des environs de Paris (fig. 1, right) makes clear. Decorative elements borrowed from topographical landscape drawing have been abandoned, and the human figure is excluded altogether. Instead, rock strata are organized along a vertical axis whose annotations reflect both their relative depth and the geological era in which they were thought to have formed. In late eighteenthand early nineteenth-century stratigraphic diagrams, geological history came into view for the first time, pictured as a function of depth.

The distinctions between these two kinds of illustrations may seem subtle, but the emphasis the stratigraphic diagram placed on geological history reflected a broader scientific preoccupation with the relative age of different rock formations. ${ }^{1}$ While not itself antagonistic to human-centric time scales, this kind of illustration participated in the emergence of a new model of geological history that left little room for human history, human agency, or human experience. Whereas the cross section of the Harz Mountains

A B S T RACT This essay examines the role of geological time in the work of the German Romantic artist Caspar David Friedrich in the early nineteenth century. It foregrounds the challenges this model of time posed for the relationship between the human and the natural-a relationship usually considered central to Friedrich's work-and for the perceptual powers of the viewing subject. REPRESENTATIONS 148. Fall 2019 @ The Regents of the University of California. ISSN 0734-6018, electronic ISSN 1533-855X, pages 30-56. All rights reserved. Direct requests for permission to photocopy or reproduce article content to the University of California Press at https://www.ucpress.edu/journals/reprintspermissions. DOI: https://doi.org/10.1525/rep.2019.148.1.30. 

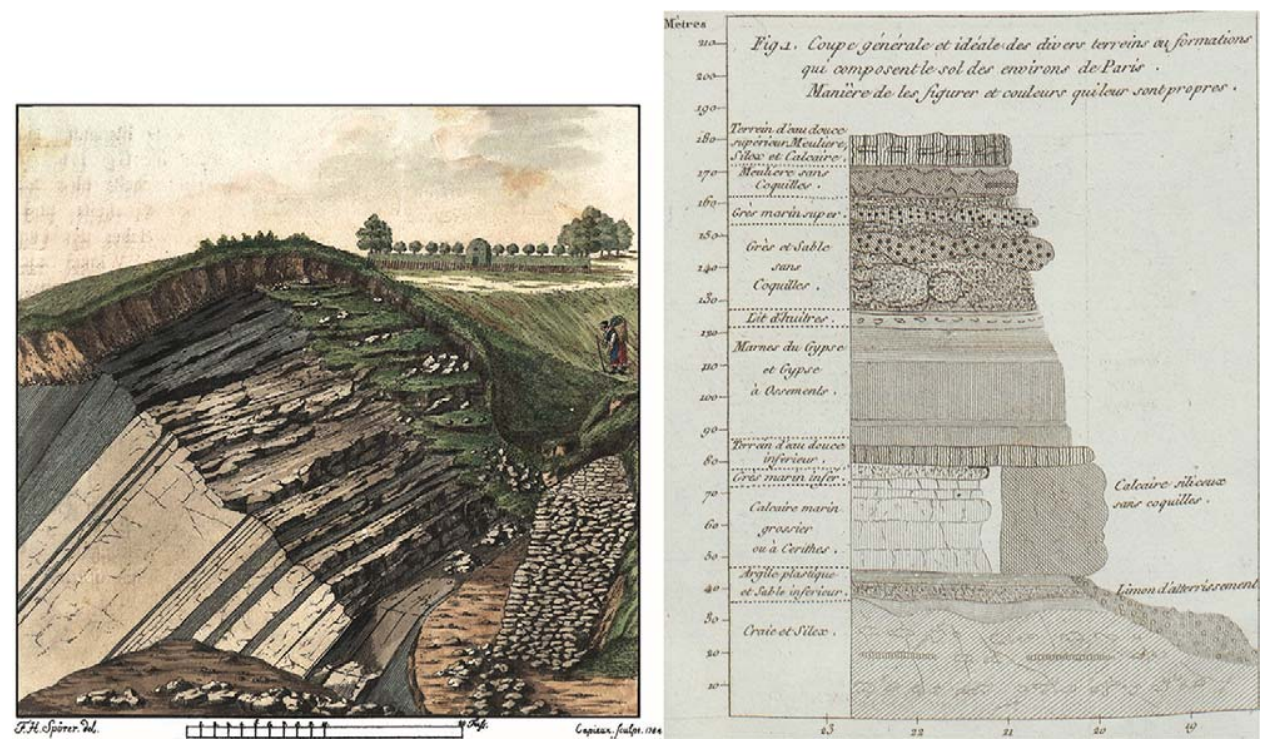

FIGURE 1. Left: Illustration by F. H. Spörer from Friedrich von Trebra, Erfahrungen vom Innern der Gebirge nach Beobachtungen gesammel (Dresden, 1805), plate 1. Digital image courtesy of the J. Paul Getty Trust's Open Content Program. Right: "Coupe générale et idéale des divers terreins ou formations qui composent le sol des environs de Paris," from Georges Cuvier and Alexandre Brongniart's Essai sur la géographie minéralogique des environs de Paris (Paris, 1811), figure 1. ETHBibliothek Zürich, Rar 2656.

integrated the human scale and the geological scale, whose compositional elements were presented in symmetrical harmony, human elements were purged in later stratigraphic illustrations or relegated to a small detail atop the uppermost strata along with the mise-en-scène of the landscape. In the intervening decades, scientists and savants alike were coming to terms with radically new accounts of how and when the earth was formed. The chronological scale used to measure geological history continually expanded as naturalists attributed ever-greater temporal depths to the rock formations that populated their world. And, correspondingly, human history occupied an increasingly small portion of that geological record; the human figure in Friedrich von Trebra's illustration was, in a sense, shrinking. This trend reached its fullest expression in the concept of "deep time" put forward by the Scottish geologist James Hutton in the final decades of the eighteenth century. ${ }^{2}$ Hutton proposed that the earth's formation took place over such a long period of time that it could not even be comprehended in terms of the time scale of human history, rendering human history 


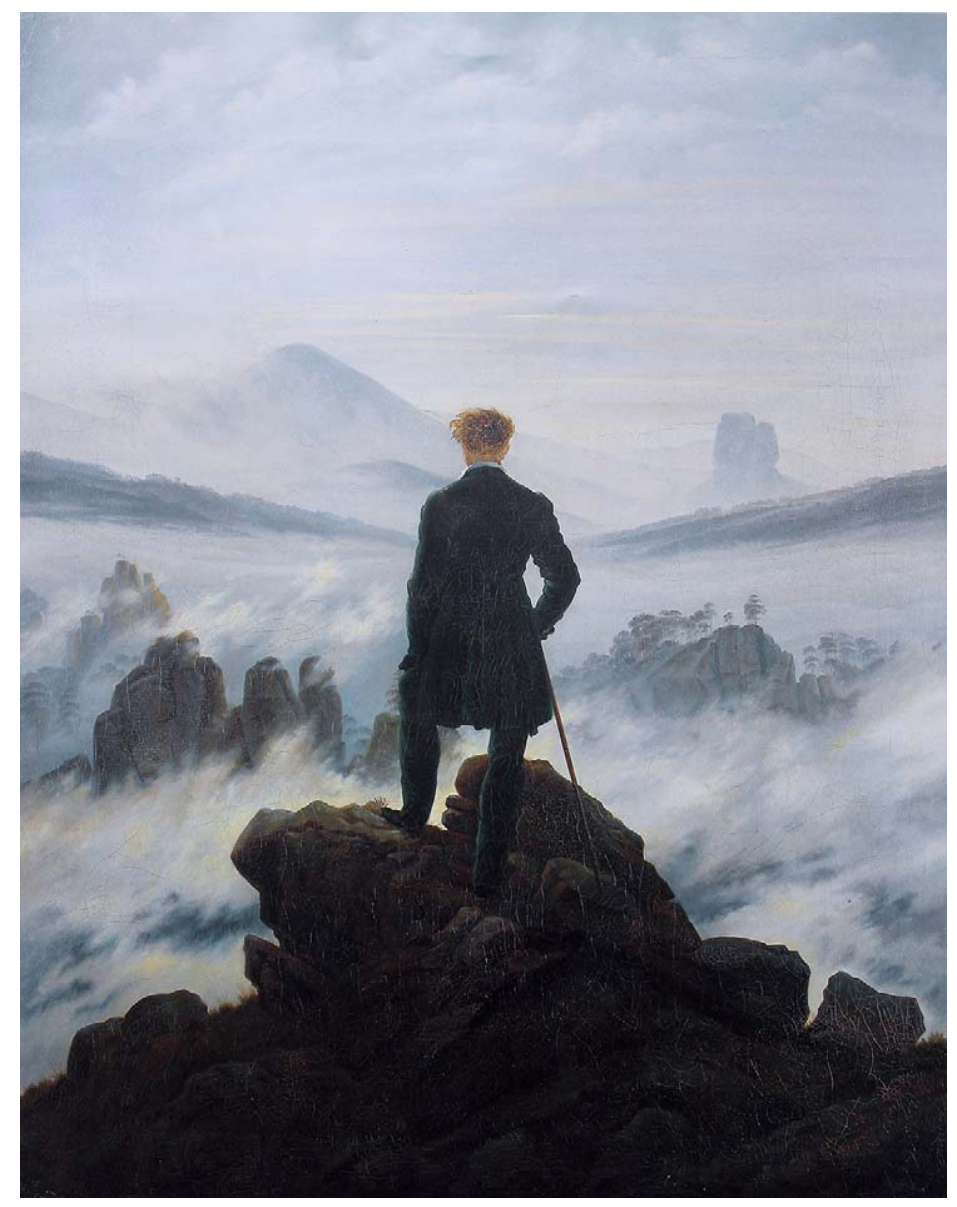

FIGURE 2. Caspar David Friedrich, Wanderer über dem Nebelmeer, circa 1817. Oil on canvas, $94.8 \times 74.8 \mathrm{~cm}$. Kunsthalle Hamburg. Photo: Wikimedia Commons.

comparatively inconsequential. ${ }^{3}$ As the sweep of geological time grew in the early nineteenth century, "human tenure on the planet" came to seem, in the words of Noah Heringman, "insignificant." 4 But in other quarters, the geological and the human were still being figured alongside each other.

Atop the rock, man. The German Romantic artist Caspar David Friedrich, known for his love of the Harz Mountains, pictured a strikingly different early nineteenth-century encounter between the human and the geological in his Wanderer Above a Sea of Clouds (fig. 2). From a granite outcropping, an eponymous wanderer placidly surveys the rocky mountain formations shrouded in mist below him and the faintly rendered peaks that flicker into view in the distance. The figure's physical elevation over his 
environment and his panoramic view suggest the fantasy of a geological landscape visually possessed and perhaps also physically mastered by the human subject. Long used as a kind of art-historical shorthand for European Romanticism in general, the painting has more recently been taken as emblematic of a model of early nineteenth-century bourgeois subjectivity concomitant with the rise of modern spectatorial practices: "the ascendancy of newly realized bourgeois aspirations, fantasies of autonomy" that, Jonathan Crary writes, "permitted at least an optical appropriation" of the natural world, if not a literal one. ${ }^{5}$ Like Crary's, a number of influential accounts of the painting grant interpretive priority to how the painting frames the role and status of the human figure qua a perceptual encounter with nature, whether mediated or direct.

Yet as a cursory inspection of the two aforementioned geological illustrations makes clear, this was a period in which the relationship between the human and the natural was undergoing extraordinary changes within mainstream scientific discourses-and in ways that posed significant challenges for the dominance assumed by a very model of subjectivity predicated on the unconstrained visual appropriation of the natural world Friedrich's protagonist seems to experience. Might this figure be poised not on a precipice but along a widening fault line between conflicting models of historical and natural time? After all, von Trebra's illustration and Friedrich's painting are not as intellectually and historically distant from each other as we might assume. Mining and geology were important elements of a constellation of cultural practices within which European Romantic thinkers like Friedrich engaged with and conceptualized nature. "It would have been difficult," Theodore Ziolkowsi notes, "to assemble a group of intellectuals in any of the centers of German Romanticism without including at least one or two guests who were somehow involved with mining" in the late eighteenth and early nineteenth centuries. ${ }^{7}$ Both Johann von Goethe and Georg von Hardenberg (better known as Novalis) were employed overseeing regional mines. ${ }^{8}$ Goethe even wrote rapturous lines about geological formations in his 1785 essay "Über den Granit." 9 As several scholars have noted, Friedrich himself possessed a genuine interest in geology and mountaineering and lived near one of Europe's foremost centers of geological research for most of his adult life. ${ }^{10}$ It is apparent that Friedrich's work might have both practical and conceptual points of contact with late eighteenth- and early nineteenthcentury geological discourse. ${ }^{11}$

From this perspective, we might consider whether several of Friedrich's works-and especially Wanderer-picture a perceptual encounter between the human and the natural that discloses not the sovereignty of bourgeois subjectivity in this period but rather its precarity in the face of divergent models of historical and natural time. In what follows, I reexamine 
Friedrich's art with a particular eye to how it frames nature and history, on its own terms and also in relation to larger trends in German Romantic thought. By placing the "geological" aspects of his work within its broader scientific context, it becomes clear that a model of subjectivity predicated on spectatorship - and particularly the act of observing the natural world—was coming under extraordinary pressure in the early decades of the nineteenth century. As an encounter between the human and the geological, do paintings like Wanderer point toward the ascendance of bourgeois subjectivity or to its imagined annihilation?

\section{Strange Encounters}

Caspar David Friedrich was born in 1774 in Greifswald, a small town in northern Germany that had been under Swedish control since the Thirty Years' War. His Protestant upbringing was materially comfortable and exceptionally devout. Friedrich also made routine visits with his father to the local university, a provincial institution, but one where subjects like topographical mapping, civil engineering, and the natural sciences were nonetheless thriving. ${ }^{12}$ The young artist received initial training from Johann Gottfried Quistorp, the university's drawing instructor and elder brother to one of the university's professors of botany and natural history. In 1794 he left Greifswald to study art at the Royal Danish Academy of Fine Arts in Copenhagen and thereafter moved to Dresden, where he remained for most of his adult life.

Friedrich's training was rooted in the practice of topographical drawing, which prized the lucid and detailed rendering of identifiable settings over the highly idealized, Arcadian tradition that had been thriving in Italy and France. From the late 1790s onward, this entailed periods of sustained travel and sketching in the German countryside, through which the artist amassed a visual archive of natural formations to which he would return months or years later to produce finished works. Despite their indebtedness to a tradition of topographical study and drawing directly from nature, Friedrich's early landscapes did not necessarily supply a clinical or detached transcription of natural formations. In Rock Gate in the Uttewalder Grund (fig. 3), expanses of diluted sepia, layered carefully atop one another, fill most of the page with the shadowy, earthen coolness of a massive rock formation. Whereas one might expect a topographical drawing to reveal a much wider middle-distance view, in Friedrich's composition vertiginous walls of rock throw up a barrier to our vision. The rock's vast scale is underscored by the inclusion of two human figures silhouetted faintly against a small wedge of light under the darkest of the boulders. Friedrich's tonal rendering of the 


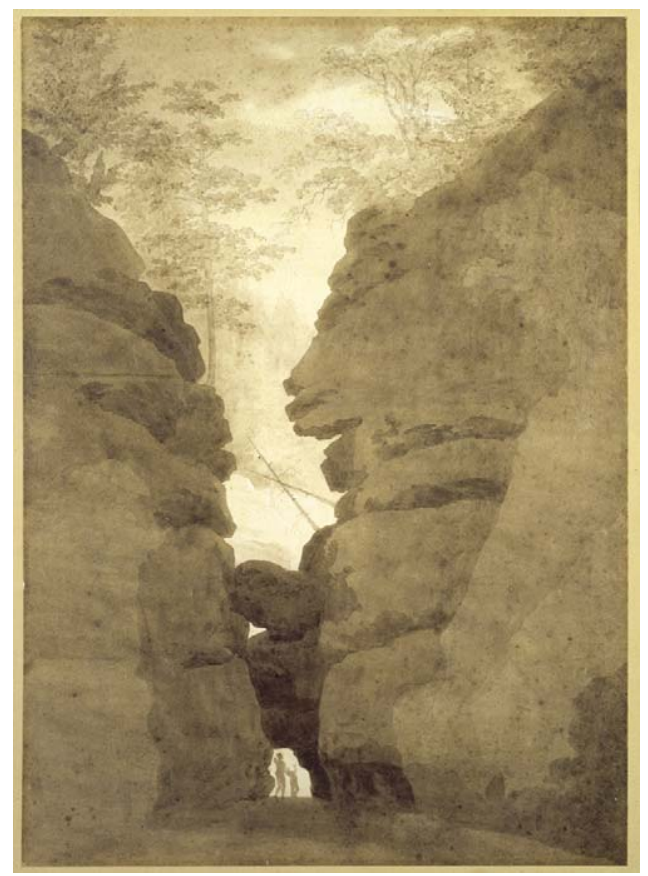

FIGURE 3. Caspar David Friedrich, Das Felsentor im Uttewalder Grund, 1800. Sepia and pencil on paper, $70.6 \times 50 \mathrm{~cm}$. Museum Folkwang, Essen. Photo: Wikimedia Commons.

gorge is evocative rather than informational, its play of light and shade dramatizing the unexpected placement of human figures below, rather than above, dense strata of earth. Rock Gate, although a relatively modest early work on paper, points to a strange coupling-topographical precision with affective intensity - and an even stranger inversion: the spatial layering of rock over human.

Friedrich's paintings in oil, a medium he did not take up until 1807, were more pointed in their divergence from the idealizing, Italianate scenes common to neoclassical landscape painting as well as from the topographical tradition that informed his early watercolors and that had been flourishing in Great Britain. Friedrich's devout Protestantism came to the fore in this context. But rather than populate the landscape with recognizable Christian iconography, Friedrich instead transposed its spiritual content onto the natural formations themselves, whose elements became obscure cyphers for affective, spiritual, and historical meaning. ${ }^{13}$ One of his earliest and most controversial works, the Tetschen Altarpiece (1807) boldly reimagined a crucifixion scene within the secular genre of landscape painting, 
producing an altarpiece in which one could more easily make out rock striations and pine fascicles than details of the cross itself. Friedrich played on the metaphor of the rock as a symbol of Christian faith and in doing so encouraged the contemplation of nature as a form of religious worship.

It is here that the putative Romanticism of Friedrich's work comes into view, for the artist invested tremendous spiritual significance in the interface-at once perceptual and psychic-between the human and the natural. As his friend Carl Gustav Carus later wrote in his Nine Letters on Landscape Painting, among the most important surviving texts on German Romantic landscapes: "Man, looking at the great whole of nature in all her splendor, becomes aware of his own littleness, and in feeling everything immediately within God, enters into this infinite totality himself." ${ }^{14}$ Both Friedrich and Carus insisted that true spiritual experience resides in man's encounter with the majesty of the natural world as God's creation. It is an experience that was clearly coded in the early nineteenth-century language of the sublime: an aesthetic in which one is confronted with and overpowered by natural grandeur in such a way as to transcend human limitations and come into contact with the divine. But in what survives of his personal writings, Friedrich also articulated an important reservation about the sensory dimension of this experience. He enjoined his fellow artists to subordinate the visual to the spiritual. "Close your bodily eye," he wrote in 1830, "so that you first see your painting with your spiritual eye." ${ }^{15}$ Perceptual experience, it would seem, has its limits.

Despite this, scholars have tended to grant interpretive priority to the formal and (to a lesser extent) historical structures through which Friedrich's viewer might identify with the perceptual vantage point presented in his works. Richard Wollheim's Painting as an Art argued that Friedrich's paintings presuppose a very particular kind of "internal spectator," a hypothetical viewer suspended above the scene with whom the painting's actual viewer is compelled to identify. ${ }^{16}$ Wollheim claims that the "occupant" of the unusually high viewpoint seen in many of Friedrich's paintings is the "nature-artist of early nineteenth-century Pietism. He is a person, or a kind of person, who, disentangled from the exigencies of material life, gains a certain detachment from nature" and thus makes nature the object of "devout contemplation." ${ }^{17}$ In order to prevent the viewer from losing his awareness of the landscape as a painted surface, Wollheim continues, Friedrich deployed a cunning pictorial device: he often included a Rückenfigur, a figure with his or her back to the viewer-the very configuration we find in Wanderer as well as a number of other works. The "shock of identifying" with the Rückenfigur in the act of viewing enables the spectator to "relinquish his identification and to pull back to a position from which the marked surface regains visibility." ${ }^{18}$ A perceptual push-and-pull seems to take place in front 
of Friedrich's paintings, one might say, whereby the viewer arrives at a detached visual and spiritual contemplation of the scene.

Writing a few years after Wollheim, Joseph Koerner described a perceptual encounter between painting and viewer that was decidedly less resolved. In Caspar David Friedrich and the Subject of Landscape, he argued that viewers of Friedrich's paintings "feel ourselves witness to a dissolution of the subject of landscape itself"-for the subject of his paintings "remains always almost visible." ${ }^{19}$ Like Wollheim, Koerner turned to the Rückenfigur to articulate the precise spectatorial and psychic dynamic at play. Koerner argued that the Rückenfigur "mediates the position of the subject in the landscape." ${ }^{20}$ We as viewers are invited to identify with the Rückenfigur, who is himself defined as a "viewer" of the landscape. Yet this is an impossible task; confronting the inexpressive and anonymous muteness of his back, which blocks the full landscape from our view, we can never fully inhabit his subject position. Both Wollheim and Koerner proposed that the process by which the viewer identifies with and recreates the perceptual experience of Friedrich's painted spectator is essential to the artwork's significatory power-and for both, interestingly, this is a process beset with internal tensions or contradictions.

In recent years, other accounts of Friedrich's paintings have emphasized the historically contingent modes of spectatorship in place in early nineteenth-century Europe. Wanderer has been compared on numerous occasions with the panorama, an immersive early nineteenth-century attraction in which spectators viewed a large-scale, 360-degree circular painting from a central platform. ${ }^{21}$ Friedrich's painted protagonist, astride a granite outcropping, is taken to resemble the panorama's viewers, who gazed upon a vast painted landscape from within the confines of a viewing platform. One of the most suggestive ironies of the attraction was that the seemingly unlimited visual access it offered the spectator was achieved only through his or her strict physical containment within the central platform. Both Stephen Oettermann and Jonathan Crary have read this tension-between visual appropriation and physical confinement-in terms of the for-profit enclosure and privatization of land then taking place throughout Western Europe. Friedrich's painting would seem to diagram a form of modern subjectivity founded on a familiar capitalist bait-and-switch: in which physical access to land is replaced by the appearance of access to land, and the latter is transformed into a commodity the individual pays to experience. ${ }^{22}$ Crary goes on to read the isolation of the Rückenfigur as emblematic of "the tragic insufficiency of the relation between subject and world" that participates in broader trends of "subjective isolation, of a sensory impoverishment and emotional privatization." ${ }^{23}$ Most recently, reading the painting in relation to contemporaneous philosophical currents, Julian Jason Haladyn 
announced that Wanderer thus reveals that "our experience of reality is perpetually mediated, and we are made to feel an increasing disconnect between self and world." ${ }^{24}$ Haladyn affirms Crary's underlying premise, namely that in Wanderer, "the role of the spectator represents the modern subject's foundational position for experiencing the world beginning in the early nineteenth century." 25

A perceptual encounter with the natural world: this is the act that, it would seem, motivates Friedrich's paintings. And the subjects of his works, whether figured or merely implied, are, in turn, defined by this act. Yet the encounter can hardly be termed a successful one. As Koerner writes of the Rückenfigur in Wanderer, he "hides with his body the very thing [he replicates]: the gaze of the subject. The hidden eye within the picture ... testifies to a powerful dimension of loss, of absence, of incompletion within the subject of Friedrich's landscapes." 26 Whether male or female (and Friedrich painted both), the Rückenfigur denies the viewer's full apprehension of the scene through his or her very presence. Each one of the accounts I have referenced found a way to write this denial into the model of visual experience (and, in some cases, subjectivity) that they attribute to his works. They also couple perceptual denial with some kind of recuperative effecta fantasy of visual possession, an evocation of that which resides beyond the visible, or a heightened awareness of the painterly surface itself. In this regard they all reflect the logic of the sublime, in which the limits of perceptual experience are confronted and then transcended. But wouldn't it be much simpler to admit that sight is precisely what is not happening in these paintings, in a fundamental sense? What would happen if we ceased privileging the sovereignty of the spectator and took more seriously the obstructions and paradoxes that seem to plague this model of perceptual experience?

\section{The Earthen Ruin}

The accounts of Friedrich's work that I have discussed so far presuppose an encounter with a relatively stable object: a natural world that stands apart from, yet is available to be perceptually apprehended by, a human subject. ${ }^{27}$ Indeed, beyond their religious evocations, Friedrich's landscapes are often said to be characterized by the dense imbrication of the human and the natural-especially apparent in his fascination with "the ruin," a common pictorial and literary trope in early nineteenthcentury Europe. The ruin summoned a past world both more authentic and more mysterious than the present. Ruined gothic abbeys and cathedrals in particular came to stand for a previous era of religious devotion 


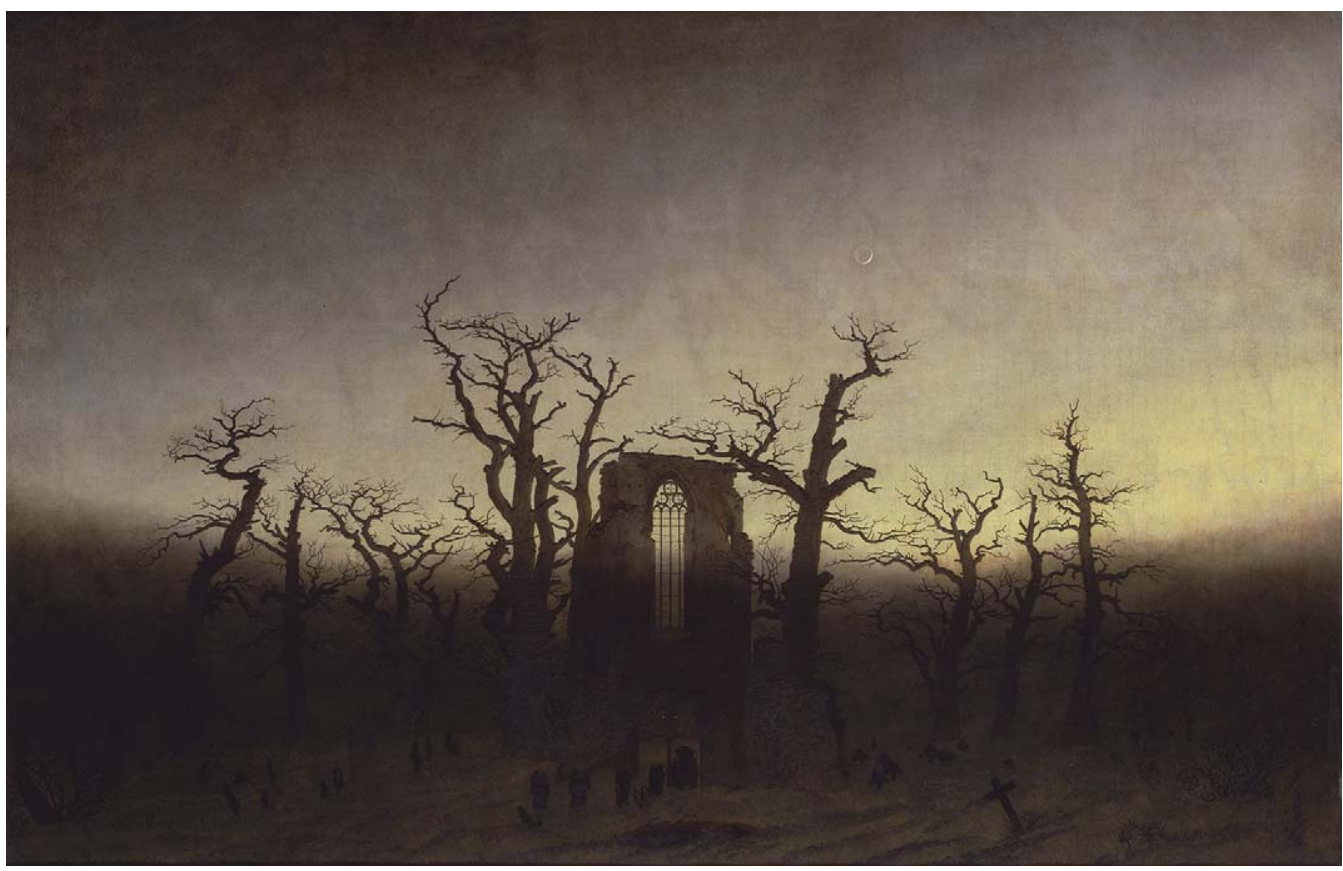

FIGURE 4. Caspar David Friedrich, Abtei im Eichwald, 1809-10. Oil on canvas, 110.4 $\times 171 \mathrm{~cm}$. Alte Nationalgalerie, Berlin. Photo: Wikimedia Commons.

that had been eroded by the secularizing tendencies of Enlightenment thought, a feature underscored by Friedrich in works like The Abbey in the Oakwood (fig. 4) through his placement of abbey ruins among towering but barren trees whose branches echo the decorative stonework of the architectural remains.

In light of Friedrich's oft-noted patriotism, the abbey's ruins may have attested to a Germanic culture with deep historical roots that were emphatically not Greco-Roman in origin. Its pointed arches and window tracery emblematize a northern European cultural patrimony that stood as a devout, Gothic alternative to the southern European neoclassical tradition. German Romantic writers thus seized upon Gothic ruins as evidence of and monuments to a remote and ennobled historical past. ${ }^{28}$ And in the context of the French Napoleonic occupation of much of what we now call Germany from 1806 to 1813, such ruins evoked an era of former glory and triumph, an association Friedrich Schlegel acknowledged rather frankly when opining that the sight of Gothic ruins "transported us far back from the present day, back to those old times when France was possessed and governed by the Germans." 29 The abbey ruins in Friedrich's painting served 
as a Denkmal, or monument, a German term that alludes to a material support for memory and reflection. ${ }^{30}$ Friedrich's Denkmal takes on a uniquely dimensional form in the architectural ruin, in which, to borrow the words of Andreas Huyssen, "history appears spatialized and built space temporalized." 31 A small, open grave in the foreground of The Abbey in the Oakwood offers up another kind of spatial repository for the casket that will be carried toward it for burial, through which human remains will be reintegrated within the landscape.

The bare, wintry terrain in which the abbey is set-a configuration found in several of Friedrich's paintings-underscores the ruin's embeddedness within a northern climate that markedly lacks the lush meadows, vibrant waterfalls, and warm diffuse light found in Italian landscapes. So closely did the artist identify topography with national identity that he complained late in life that those who criticized his paintings were "no longer satisfied with our German sun, moon and stars, our rocks, trees and plants, our plains, lakes and rivers." 32 In this regard, like many German Romantic thinkers of his generation, he was sympathetic to the ideas propagated by the influential Enlightenment philosopher Johann Herder, who argued that landscape and climate play a decisive role in shaping the unique features of a given culture. Herder's climatological account of cultural difference suggested that both individual and collective identity were profoundly embedded within the natural environment.

From this vantage point, it is tempting to conclude that Friedrich conceived of a natural world in harmony with human history, even if nature's grandeur remained aesthetically and spiritually superior to the manmade world. But whereas Goethe was inclined to see natural forms and human actions striving toward some kind of essential ideal or unity, it is far from obvious that Friedrich's painting promises such an outcome. Natural revival remains possible: the bare trees that tower over a once-great human monument will sprout leaves as the season changes, the crescent moon seen in the painting's distance will grow large again, even the snow that blankets the scene in gloomy silence will gradually melt. But no natural processes can restore the ruined abbey to its former greatness; they can only precipitate its further dismantling. The Abbey in the Oakwood recalls, in this sense, Rock Gate from almost a decade earlier, insofar as both picture a stony façade that dwarfs the human figures who pass beneath it. In each work, the human is silhouetted against a small aperture-like opening at its base while the only living forms seen above the mass of rock are arboreal. The comparison evokes a natural world in which the sphere of human activity does not take spatial or geological priority. It also leads us to an observation of startling simplicity: the abbey remains are usually read as an emblem of a human past, but in material terms they are made of hewn rock, the stuff of the earth's past. 


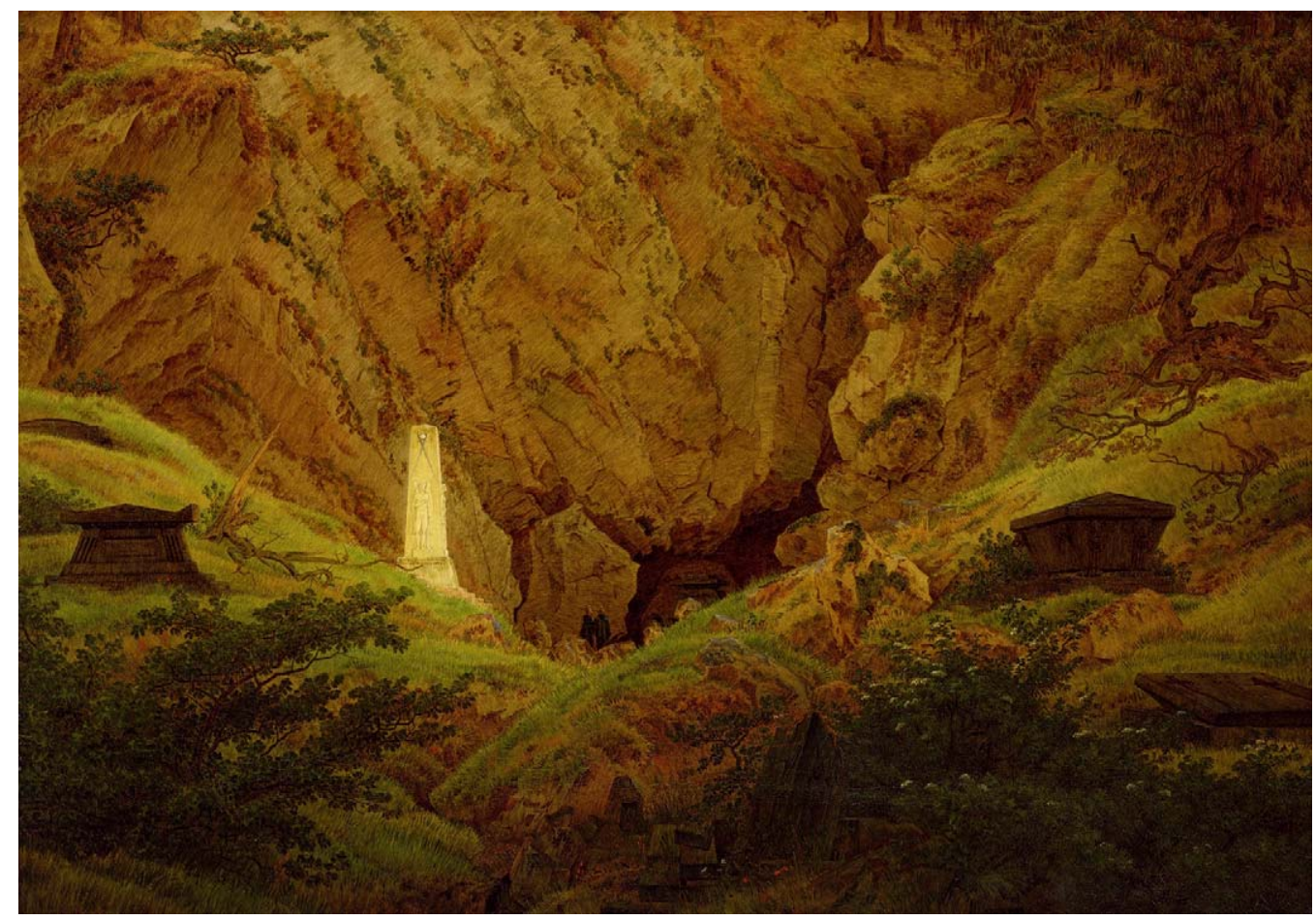

FIGURE 5. Caspar David Friedrich, Gräber gefallener Freiheitskrieger, 1812. Oil on canvas, $49.3 \times 69.8 \mathrm{~cm}$. Kunsthalle Hamburg. Photo: Wikimedia Commons.

The process of ruination merely enacts its return to a former natural state, its stone masses reabsorbed by the earth once more. The abbey as an emblem of human achievement amounts to little more than a temporary reconfiguration - an intermediate phase-in which natural formations had been briefly transformed by the human.

Friedrich's Tomb of Fallen Freedom Fighters (fig. 5) makes the point even more forcefully. Consider, for example, the compositional affinities between the ponderous stone tombs in the midground and the darkened spatial recess within the rock formation behind them. Both are rocky enclosures that absorb the material remains of human life and endure long after that life has ended. They evoke a geological past and possibly also a geological future marked by the absence of living human actors. Paintings like this make it difficult to claim that Friedrich's work is straightforwardly contiguous with late eighteenth-century German Romantic historicism-that it triumphantly unites human history and natural history within the landscape. Instead, cultural monuments and sacred human rituals occupy a temporal scale that dims in significance when compared to that of nature. Set against 
the accumulation of rocky strata, human activity comprises a small sliver of time and space.

It could be, though, that there's another kind of monument being commemorated here. The earth is figured as a material receptacle for the past; its very matter-fossils-preserve the physical remains of what came before. Might the land itself, as a Denkmal, be the material incarnation of its own past, a physical space through which history can be apprehended? Nature as a ruin or, even, an archive. Reading Friedrich's landscapes this way is to see them alongside a rhetorical and conceptual tradition that had played an increasingly significant role in certain strands of mid- and late eighteenth-century science. In the final decades of the eighteenth century, natural history and antiquarianism were closely aligned both in theory and in practice. The eminent French naturalist Georges-Louis Leclerc, better known as the Comte de Buffon, famously referred to fossils as "antiquities of the earth" and "the archives of nature." 33 This trope-nature as itself a historical artifact from earth's past-could be found in both scientific and philosophical texts and reflected a growing interest in mineralogy and geology. For example, the German naturalist and racial anthropologist Johann Friedrich Blumenbach, a correspondent of Immanuel Kant's, described petrified organic matter (such as fossils and sediment), as "the most infallible documents in the archive of nature." ${ }^{34}$ This trope pervaded mainstream discourses of natural history, a subject of great interest to Romantic writers like Goethe, F. W. J. Schelling, Heinrich von Kleist, and Novalis. ${ }^{35}$ In Friedrich's work, we could say, the layering of human acts of memorialization within and beneath rocky strata opens onto a conception of the natural world as a ruin or archive of the nonhuman.

\section{Geological Landscapes}

The limitations of a perceptual encounter with nature and the recognition of earth's nonhuman histories were both familiar concepts in one prominent corner of intellectual and scientific thought in the early nineteenth century: the nascent field of what is now called geology. Over the course of the eighteenth century, geology was a subject increasingly conceptualized as historical-that is, the study of the formation of rocks became synonymous with the study of the history of the earth. ${ }^{36}$ In 1765 a mining academy was founded in Freiberg, a short distance from Dresden. Die Technische Universität Bergakademie Freiberg (Freiberg University of Mining and Technology) was one of the foremost international centers for geology and mining in late eighteenth-century Europe. A number of influential intellectuals and scientists studied there, including Alexander von 
Humboldt, Novalis, and the natural scientist Henrik Steffens, a friend of Friedrich. Because mining concerned itself with the rock layers that comprise the earth's crust, its study inevitably led to accounts of how and why such layers had been originally formed; thus research in mineralogy and mining was closely linked to the history and structure of the subterranean world, what was then called geognosy. By the late seventeenth century numerous theories of "stratigraphic succession" had been developed, and in the eighteenth century interest in stratigraphy spread throughout Europe. ${ }^{37}$

Few thinkers were more influential in this trend than the German mineralogist Abraham Gottlob Werner, who taught at the Freiberg mining academy from 1775 until his death in 1817. Werner's work on stratigraphy was crucial to the emergence of geology as distinct from mineralogy and natural history. ${ }^{38}$ His interest lay primarily in locating and identifying layers of mineral deposits rather than in crafting a grand theory of the formation of the earth, but the latter proved somewhat inescapable: because Werner, like many of his contemporaries, believed that different types of rocks appeared in a very specific and consistent order, identifying different rock layers was concomitant with identifying geological time periods. Werner belonged to a larger European school of thought that proposed that the earth had been formed as a result of the activities of a primeval, universal ocean. Out of that ocean crystalline rock was precipitated, which covered the core of the earth. As the water receded, continental land masses were formed that divided the primeval ocean into smaller bodies of water, and successive transitional layers of rock likewise precipitated. Because this account treated water as the primary shaping force of the world, it was referred to as "Neptunism." Werner concluded that the crystalline rock granite was the oldest kind of rock and could thus be found both at the depths of the earth and at its peaks. Werner's account of the formation of the earth more or less dominated geological discourse in scientific and lay communities throughout the German-speaking states at the turn of the nineteenth century and was a subject of widespread discussion among the educated circles of Dresden, where Friedrich lived.

Broadly speaking, mountains-and above all the Alps—-were a subject of general interest among Europe's educated elites. ${ }^{39}$ Friedrich never studied under Werner despite his close proximity to the Freiberg mining academy and his intimate friendships with several of its students. Yet we know that he counted among his interests mountaineering, "geology, meteorology, and botany." ${ }^{40}$ Friedrich was unusual for a landscape painter of his generation in his refusal to travel to the Swiss Alps, preferring instead the Riesengebirge and the Harz Mountains, the latter of which attracted specialized geological attention for their fossil deposits and unusual rock formations. ${ }^{41}$ The 


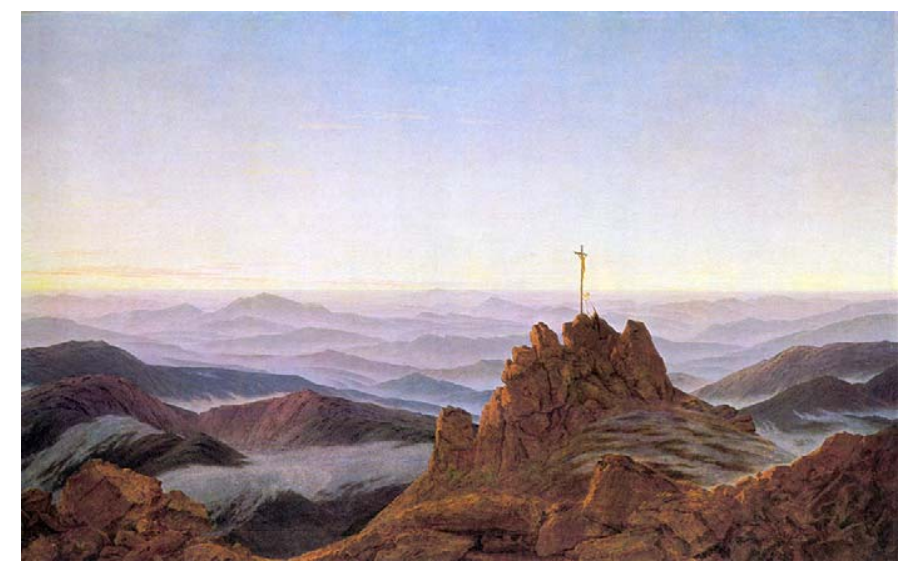

Figure 6. Caspar David Friedrich, Morgen im Riesengebirge, 1810/1811. Oil on canvas, $108 \times 170 \mathrm{~cm}$. Alte Nationalgalerie, Berlin. Photo: Wikimedia Commons.

Saxony mountains, which possessed a granite superstructure, even supplied the minerals for some of the pigments used by Friedrich and other Dresden painters. ${ }^{42}$

Granite, the originary rock in Werner's theory of the earth's formation, features prominently in Friedrich's landscapes. His Morning in the Riesengebirge (fig. 6) from 1810 or 1811, for example, quite literally foregrounds the rock. Its jumbled density recalls Goethe's poetical description of granite from 1785: "shot through with cracks, here rising straight up, there skew, sometimes sharply layered, sometimes in formless heaps as though thrown together." ${ }^{3}$ The distant peaks spreading out below it are partly obscured by expanses of fog that have settled into the valleys overnight. The painting's lucid transcription of the varied peaks and its careful attention to the particular formations for which the Riesengebirge is known speak to the tradition of topographical drawing in which Friedrich was initially trained. But Friedrich also suppressed a great deal of information about the scene under a thick blanket of clouds, whose blue tonalities have the uncanny effect of transforming the obdurate materiality of rock into a vaporous sea of mist. It's an effect that, Albert Boime has argued, resembles "Werner's primordial chemical soup, out of which the primitive granite rocks crystallized." 44 The water cycle is likewise seemingly alluded to; geognostical theory dictated that vapor grew denser among the high, cold mountains where it was transformed back into fresh water and returned to the earth.

Friedrich's two paintings most explicitly associated with geology both date to the mid-1820s, and both are of Alpine mountain ranges that Friedrich 


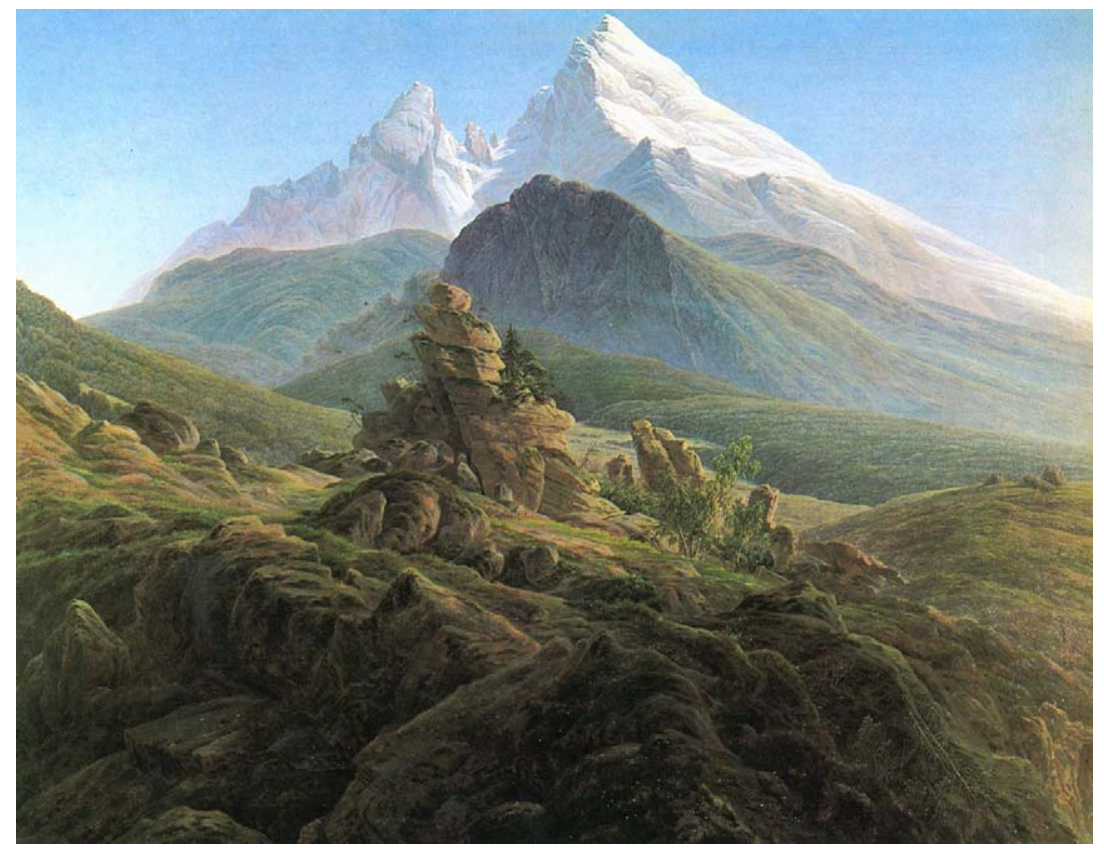

Figure 7. Caspar David Friedrich, Der Watzmann, 1824/1825. Oil on canvas, $135 \times$ $170 \mathrm{~cm}$. Alte Nationalgalerie, Berlin. Photo: Wikimedia Commons.

himself never saw, which was quite unusual for the artist. ${ }^{45}$ Hochgebirge ("high mountains"; destroyed in 1945), completed in or around 1824, was instead based on drawings of the Chamonix Valley made by his friend, the amateur painter and naturalist Carus, who had visited the Alps in 1821 at the urging of Goethe. As Timothy Mitchell has noted, the "Swiss peaks that appear in Hochgebirge are granite peaks and thus represent Urgebirge," or primordial rock, according to Werner. ${ }^{46}$ In contrast, The Watzmann (fig. 7) is made of what Werner classified as Floetzgebirge, the second rock type formed after granite as the waters of the primeval ocean receded. Yet, as Mitchell has argued, Friedrich took exceptional topographical liberties with his composition, compressing and elongating the mountain itself and placing in the foreground a well-known granite rock formation from an entirely different mountain range (the Harz Mountains), which Friedrich had visited in 1811. Mitchell argues that Friedrich sacrificed topographical accuracy in order to convey a more fundamental geological truth: he places the recognizable granite (or Urgebirge) outcropping in the foreground as evidence of the history of the earth's formation. Granite is spatially and geologically primary in Friedrich's composition; it is the material and 


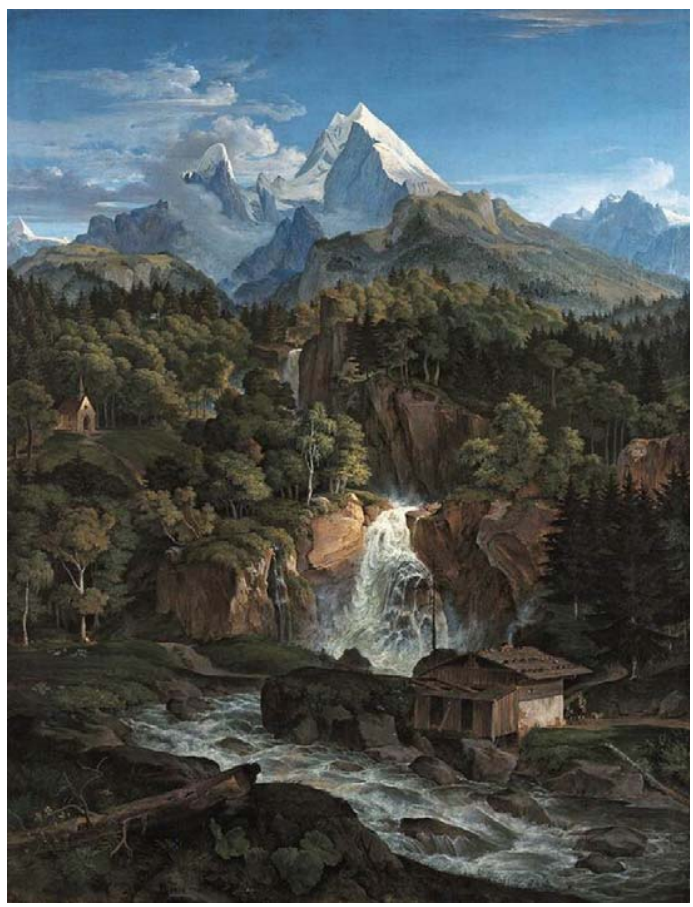

FIGURE 8. Adrian Ludwig Richter, Watzmann, circa 1824 . Oil on canvas, $121 \times 93.5$ cm. Neue Pinakothek, Munich. Photo: Wikimedia Commons.

chronological precondition for the secondary type of rock seen on the distant peaks of the Watzmann.

The Watzmann had recently been the subject of a well-received painting produced by a young German artist then studying in Rome, Adrian Ludwig Richter. Richter's Watzmann (fig. 8) exemplified many of the Italianate features Friedrich had deliberately excluded from his work, whose popularity was, in the 1820 s, noticeably waning. Whereas Richter placed a wooden architectural structure in the foreground and another one in the midground, Friedrich suppressed any indication of human life in his painting - a feature common to his later landscapes. In combining the mountain view with a waterfall, Richter had produced a composite image that united multiple elements of the neoclassical sublime. Friedrich wrote disdainfully of this practice: "What today's landscape painters have seen in an arc of 100 degrees in nature they mercilessly squeeze into a 45-degree angle of vision. And things that were separated in nature by large intervening spaces are crowded together... overfilling and oversaturating the eye, and making an unpleasant, alarming impression on the viewer." 47 This pronouncement, 
it has to be said, makes his own topographical composite in the foreground all the more enigmatic.

Richter's inclusion of the waterfall serves an important compositional purpose: it links the distant white peaks of the Watzmann with the intervening spatial registers, flowing down in the midground and opening, in the foreground, into the space most proximate to the viewer. It offers a topographical and visual pathway into the depths of the painting and toward the mountain. Friedrich's composition, in contrast, withholds this possibility. In the lowermost register of the painting a shaded rocky mass seems to bar one's entry into the scene. Instead, one's eye must travel into the spatial recesses of the painting by traversing a series of diagonal lines that zig and zag across the canvas, marking the boundaries of different topographical formations. In both of his Alpine paintings, Friedrich uses such diagonals to produce compositions of nested triangles and inverted triangles. As a result, the eye travels $u p$ the painting rather than into the painting. Insofar as these images contain chronostratigraphic layers, in which the vertical axis registers both depth and time, Friedrich's paintings can be read as an appeal, once again, to the prehuman historical profundity of the region, to a geological antiquity that was distinct from the southern European landscape and the Greco-Roman tradition it gave rise to.

\section{Unconformities}

Though historians like Boime and Mitchell have delineated points of overlap and exchange between Wernerian geology and Friedrich's work, at the turn of the nineteenth century a rival theory was gaining traction that would decisively triumph over Wernerian geology by the 1820 s. $^{48}$ The Scottish naturalist James Hutton put forward a radically different account in his Theory of the Earth, first published in 1788 and republished in 1795 as a two-volume edition. Whereas Werner was a "Neptunist" who believed that water was responsible for the formation of rocks, Hutton represented an alternative faction of "Vulcanists" who asserted that heat from the earth's core was the determinant factor. Hutton rejected one of the basic tenets of Wernerian geology, claiming that there is no such thing as originary rock. He argued that the earth's strata result from a continuous cycle of erosion and deposition: land is slowly worn down by running water that is carried, as sediment, and deposited on the sea floor. There, the sediment is compressed and lithified by heat from the center of the earth, and this newly fused rock is eventually elevated above water as new dry land. In place of Werner's unidirectional narrative of the earth's formation, Hutton proposed a cyclical model with no determinate "origin" state 


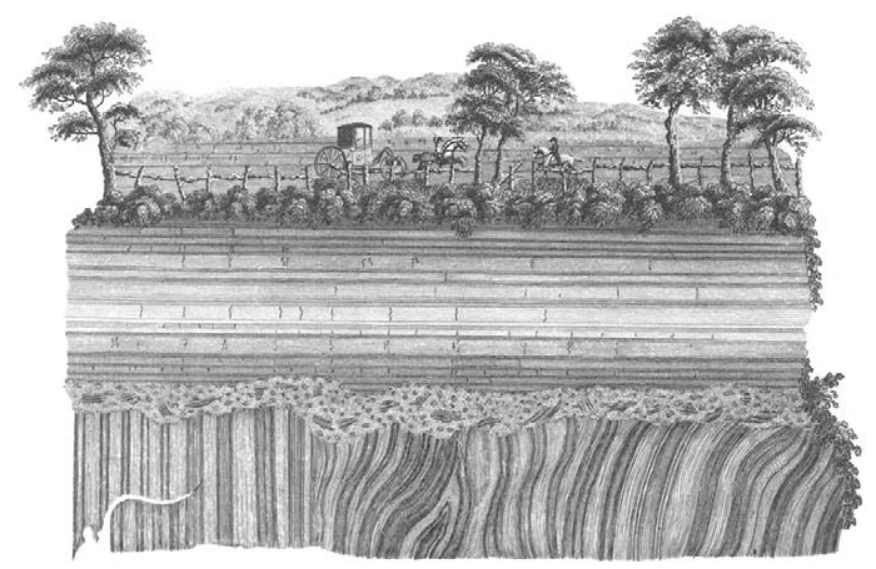

FIGURE 9. After John Clerk, illustration from James Hutton, Theory of the Earth, (Edinburgh, 1795), 1: plate 3.

nor point of completion. The earth was said to undergo endlessly repeated cycles of erosion, sedimentation, fusion, and elevation that produced a state of dynamic equilibrium.

Hutton identified "unconformities" (fig. 9) in the earth in which horizontal strata were interrupted by a set of differently angled strata from a much earlier moment that had been pushed upward. He recognized them as evidence of a significant gap in the sedimentary record, alluding to a cycle of erosion and deposition that extended much farther back in time than had previously been deemed possible. Hutton coined the term "deep time," which alludes both to the conjoining of physical depth with geological time and to the notion that an entirely different scale of time would be needed to account for geological events. Werner had estimated that the earth took shape over the course of roughly one million years. ${ }^{49}$ However, deep time differed radically even from Werner's expansive sense of geochronology: the challenge that lay in deep time was that it was not simply vast but theoretically limitless or infinite. Hutton's friend John Playfair, upon seeing one of Hutton's unconformities, called it "the abyss of time." 50

Deep time names a chronology so vast that it is fundamentally nonhuman in its orientation. It demands that humans conceptualize the decisive, monumental physicality and significance of events that unfold outside any human frame of reference. It is, in the words of Stephen Jay Gould, a concept "so alien that we can really only comprehend it as a metaphor." ${ }^{11}$ Both Martin Rudwick and Heringman have written extensively on the intellectual and even existential problems it poses to humancentric models of history, agency, and experience: it is not merely that the human vantage point is 
insufficient; it is itself so insignificant as to be meaningless. ${ }^{52}$ Above all, I want to emphasize the threat this concept poses to models of knowledge production that grant any kind of epistemological priority to human experience. From within the frame of human history, geological events are too slow to come into view. They cannot be directly apprehended. Consequently, they are difficult to integrate into an empirical model of observation-based scientific knowledge. Deep time thus marks "real epistemological limits" on human perceptual experience. ${ }^{53}$ Hutton himself was keenly aware of this problem, writing in 1785 that "there is not in human observation proper means for measuring" the erosion and deposition of earth's matter. ${ }^{54}$ "How shall we acquire the knowledge of a system calculated for millions, not of years only, nor of the ages of man, but of races of men, and the succession of empire?" he asked. ${ }^{55}$ Because the effects of deep time were unobservable, Hutton was obliged to abandon empirical means and rely instead upon deductive reasoning. ${ }^{56}$ Around the turn of the nineteenth century, Huttonian geology marked divergent models of natural time and human time in ways that ultimately diminished the epistemological authority of perceptual experience itself.

How could we go about making sense, from this perspective, of Friedrich and his solemn boulders, granite peaks, and mist-filled valleys? My aim here is not to argue for Huttonian over Wernerian geology as a privileged explanatory framework. (Although Hutton's ascendance is something the scholarship on the "Wernerian" aspects of Friedrich's paintings should take into account.) The point I would like to make is, in some regards, much more basic. It concerns the relationship between the human subject, geological matter, and the perceptual encounter at the center of so much of the scholarship on Friedrich. Recall that for Wollheim the "internal spectator" of Friedrich's paintings compels the viewer to retreat to a detached perspective from which she or he recognizes the landscape as a painted surface. According to Koerner, the Rückenfigur signals the never quite fully visible nature of the world, whose subject is characterized by psychic and perceptual suspension. Both accounts are organized, whether implicitly or explicitly, around the human subject as a spectator. With the ecological turn in mind, people like Bruno Latour have tried to rethink Friedrich's works in nonhuman terms, as offering an image of the world whose consummate strangeness reflects its refusal to be oriented toward a human vantage point. ${ }^{57}$ Writing recently for Latour's Reset Modernity! project, Koerner has likewise reflected on Friedrich's portrayal of a world "set ineluctably apart from the human subject," a world of "inhuman immensity." 58

But deep time offers a much more fundamental challenge: a world that annihilates the human subject—not merely as a biological entity but as a temporal, perceptual, or subjective positionality. In the early decades of 
the nineteenth century, the current state of the world could no longer be considered the fixed, final state of a unidirectional historical sequence but simply the present iteration of a constantly changing world without origin or endpoint. ${ }^{59}$ It was not merely the scale but also the logic of geological time that broke with a unidirectional understanding of human time. Deep time, then, radically deprivileged the human subject and above all the epistemological authority of human comprehension and experience: "It is in vain to attempt to measure a quantity which escapes our notice, and which [human] history cannot ascertain," Hutton wrote in defense of his deductive method. ${ }^{60}$ This sentence condenses the two fundamental challenges at work in deep time: its incomprehensibility relative to human history, and its denial of human observation. Man's powers of perception proved completely inadequate.

The geological, in other words, is exactly what Friedrich's Wanderer cannot see. Instead, the human comes to stand for the blockage of the very mastery for which he seems to aspire. Even the landscape that opens up on either side of his upright figure is barely available to be seen and made sense of. The dense white mist that fills the valley conceals the base of the granite peaks that populate the midground; neither the painting's viewer nor its protagonist can plumb their depths. Their geological heft remains hidden below the threshold of our sight. The partial obscurity of the scene has been read in terms of the sublime, but sometimes obscurity is just that-without the assertion of man's powers of reason over nature, as Kant would have it. ${ }^{61}$ The perceptual encounter between human and nature is, within the context of deep time, antithetical to the recuperative model of aesthetic experience put forward in both Kantian and Burkean theories of the sublime. We confront, instead, a historically specific alternative to the sublime that does not proclaim the experiential or intellectual triumph of the human subject. Obscurity as such marks a relatively straightforward limit to what can be seen and what can be known-a limit that was, it should now be clear, central to the era's geological debates. Even the granite outcropping upon which the wanderer stands, a shadowy wedge that darkens the foreground and further obscures the scene, is itself difficult to see the precise contours of at its base. If the panorama promised its spectators an unbroken horizontal expanse of visibility, it bears strikingly little resemblance to the pictorial field presented to Friedrich's viewer, whose sight is thwarted at every turn.

Rather than the assertion of bourgeois subjectivity predicated on the visual apprehension of the natural world, we confront a conception of geological time that stands completely at odds with human historical time and the perceptual experience of the human subject. Insofar as it remains productive to think about Friedrich's work in terms of a model of subjectivity grounded in spectatorial practices, though, the painting might not 
be as incompatible with Huttonian deep time as it initially appears. After all, the human figure may be given compositional priority, yet he is present precisely where the geological formations cannot be seen. Instead of reading his occlusion of the landscape as a paradox that must be accounted for, could we not say that-geologically speaking - this is the very point? The human and the natural are adjacent, but each comes into view where the other is absent. They are, in fact, mutually exclusive. The media historian Siegfried Zielinski has suggested that deep time offers an alternative to progress-oriented, genealogical media histories. Zielinski takes the theorization of deep time as an opportunity to recognize the heterogeneity of subterranean histories, metaphorical "unconformities." Zielinski's history of the nonhuman here concerns technology, rather than Hutton's earthly matter. More in line with the geological, however, are ecological paradigms that insist upon a dynamic conception of agency that is not exclusively human. ${ }^{62}$

Friedrich's geological time extended backward without humans; today we reckon with the prospect of a geological time extending forward without humans, a world whose history continues after our own extinction. ${ }^{63}$ If deep time announces a model of geological agency that eclipses that of the human, perhaps its most dramatic expression in Friedrich's work can be found in Sea of Ice (fig. 10), an arctic scene of natural destruction. The triangular arrangement of block-like ice floes in the midground and background resemble the granite formations found in several of Friedrich's other landscapes. The lowermost register of the painting is entirely given over to the detailed rendering of ice strata whose geometric density resembles in no small measure the kinds of formations Friedrich studied while traveling through the Harz Mountains. Formerly referred to as The Wreck of the Hope, the painting depicts a capsized vessel that is only partly glimpsed through dense plates of broken ice, having been presumably crushed by the accumulating floes. Its mast is parallel with the steep shafts of ice that sweep up the right side of the central triangular formation. The painting of course suggests the futility of human endeavors when they are set against the power of the natural world. Read stratigraphically, though, it can also be said that the human - a diminutive presence, to be sure-is being integrated into the strata of ice and rock that lie atop one another in the foreground. The human enters metaphorically-for here, we are dealing with ice rather than rock itself-the cycle by which the natural world is broken up and resedimented and through this process is absorbed into the deep abyss of geological time. At arguably the dawn of an era when the human became the determinate factor in planetary change, the imaged insignificance of the human in the face of nonhuman agency is, at the very same time, a reminder of the enfolding of the human into the earth itself. 


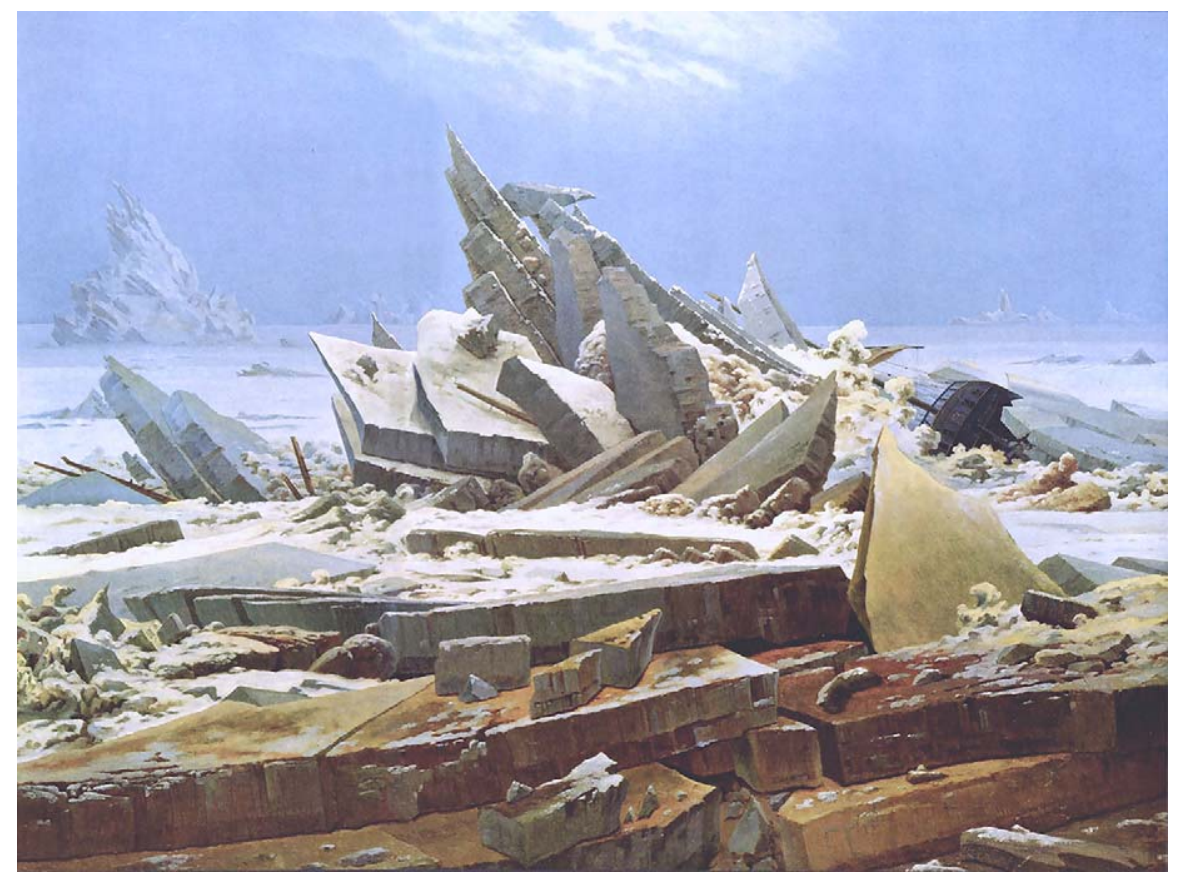

Figure 10. Caspar David Friedrich, Das Eismeer, 1823/1824. Oil on canvas, $96.7 \times$ $126.9 \mathrm{~cm}$. Kunsthalle Hamburg. Photo: Wikimedia Commons.

\section{Notes}

I am grateful to Sam Rose, Trevor Stark, Marika Knowles, and Whitney Davis for their invaluable insights and editorial support. James Rae and Andrea Burke provided key geological expertise. Feedback from the editorial board of Representations has helped to greatly improve the entire essay, for which I offer thanks.

1. Martin Rudwick, "The Emergence of a Visual Language for Geological Science, 1760-1840," History of Science 14 (1976): 149-95. See also Nicolaas Rupke, “The End of History' in the Early Picturing of Geological Time," History of Science 36 (1998): 61-90.

2. James Hutton's claims initially appeared in print in 1788 , but an expanded and more decisive two-volume version of the theory was published in 1795 as Theory of the Earth.

3. Stephen Jay Gould, Time's Arrow, Time's Cycle: Myth and Metaphor in the Discovery of Geological Time (Cambridge, MA, 1987).

4. Noah Heringman, "Deep Time at the Dawn of the Anthropocene," Representations 129 (2015): 56-85. 
5. Jonathan Crary, "Géricault, the Panorama, and Sites of Reality in the Early Nineteenth Century," Grey Room 9 (Autumn 2002): 22. One of the more recent examples is Julian Jason Haladyn, "Friedrich's Wanderer: Paradox of the Modern Subject," RACAR: revue d'art canadienne 41, no. 1 (2016): 47-61.

6. Noah Heringman, Romantic Rocks, Aesthetic Geology (Ithaca, 2004). John Wyatt, Wordsworth and the Geologists (New York, 2005). A seminal text on this subject is Marjorie Hope Nicolson's Mountain Gloom and Mountain Glory (Ithaca, 1959). Andrew Graciano has written about geology in eighteenth-century British landscape painting in "The Book of Nature is Open to All Men': Geology, Mining, and History in Joseph Wright's Derbyshire Landscapes," Huntington Library Quarterly 68, no. 4 (2005): 583-600. David Bindman, "John Martin, Thomas Cole, and Deep Time," in Transatlantic Romanticism: British and American Art and Literature, 1790-1860, ed. Andrew Hemingway and Alan Wallach (Amherst, 2015), 171-82. As recent scholarship on the American context has shown, nineteenth-century landscapes were likewise drawing upon geological conceptions of nature. Angela Miller, "The Fate of Wilderness in American Landscape Art: The Dilemmas of 'Nature's Nation,'” in A Keener Perception: Ecocritical Studies in American Art History, ed. Alan Braddock and Christoph Irmscher (Tuscaloosa, 2009): 85-109. Jennifer Raab, Frederic Church: The Art and Science of Detail (New Haven, 2015). Virginia Wagner, "Geological Time in Nineteenth-Century Landscape Paintings," Winterthur Portfolio 24, no. 3/4 (1989): 153-63.

7. Theodore Ziolkowski, German Romanticism and Its Institutions (Princeton, 1990), 20.

8. Heather Sullivan, "Collecting the Rocks of Time: Goethe, the Romantics, and Early Geology," European Romantic Review 10 (1999): 1-4, 341-70; Werner Busch, "Der Berg als Gegenstand von Naturwissenschaft und Kunst: Zu Goethes geologischem Begriff," in Goethe und die Kunst, ed. Sabine Schulze (Stuttgart, 1994), 485-97; George Wells, Goethe and the Development of Science, 1750-1900 (Alphen aan den Rijn, 1978), 47-69; Timothy Mitchell, Art and Science in German Landscape Painting, 1770-1840 (New York, 1993).

9. On Johann von Goethe and geology, see also Wolf von Engelhardt, Goethe im Gespräch mit der Erde (Weimar, 2003); and Wolfgang Schimer and Heike Spies, Goethe, Gneis und Granit (Düsseldorf, 2005).

10. Albert Boime, A Social History of Modern Art: Art in an Age of Bonapartism, 1800-1815 (Chicago, 1993), 2:512-60. Timothy Mitchell, "Caspar David Friedrich's Der Watzmann: German Romantic Landscape Painting and Historical Geology," Art Bulletin 66, no. 3 (1984): 452-64. Nicholas [Nicolaas] A. Rupke, "Caves, Fossils and the History of the Earth," in Romanticism and the Sciences, ed. Andrew Cunningham (New York, 1990), 241-59. An unpublished but nonetheless valuable trove of information can be found in Catherine Clinger, "Caspar David Friedrich and the Catachthonic Cultures of Romantic Science and Technology" (PhD diss., University College London, 2007).

11. The importance of the natural sciences for Friedrich is addressed in a number of sources, including Nina Amstutz, "Caspar David Friedrich and the Anatomy of Nature," Art History 37, no. 3 (2014): 454-81. Nina Amstutz, "A Self-Portrait as Landscape Painter: Caspar David Friedrich and Phrenology," Zeitschrift für Kunstgeschichte 79, no. 1 (2016): 72-91. Werner Busch, Caspar David Friedrich: Ästhetik und Religion (Munich, 2003), and Mitchell's Art and Science in German Landscape Painting. A number of major exhibitions have addressed this topic; see, for example, the exhibition catalog Expedition Kunst: Die Entdeckung der 
Natur von C. D. Friedrich bis Humboldt, ed. Jenns Eric Howoldt and Uwe M. Schneede (Hamburg, 2002).

12. Detailed information on Friedrich's activities at the university is somewhat limited. See Boime, A Social History of Modern Art, 512-13.

13. See Busch, Caspar David Friedrich; Joseph Leo Koerner, "Art as Religion," in Caspar David Friedrich and the Subject of Landscape (London, 1990); Robert Rosenblum, "Friedrich and the Divinity of Landscape," in Modern Painting and the Northern Romantic Tradition: Friedrich to Rothko (New York, 1975). Helmut BörschSupan terms these formations "hieroglyphs" in his Caspar David Friedrich (Munich, 1990), 8-12.

14. Carl Gustav Carus, Neun Briefe über Landschaftsmalerei: geschrieben in den Jahren 1815-1824 (Leipzig, 1831), 36. Translations are the author's unless otherwise noted.

15. Caspar David Friedrich, “Äußerung bei Betrachtung einer Sammlung von Gemälden von größtenteils noch lebenden und unlängst verstorbenen Künstlern" (c. 1830), in C. D. Friedrich, Bekenntnisse, ed. K. K. Eberlein (Leipzig, 1924), 121.

16. Richard Wollheim, Painting as an Art (London, 1987), 136.

17. Ibid., 133.

18. Ibid., 168.

19. Koerner, Caspar David Friedrich and the Subject of Landscape, 15 and 20.

20. Ibid., 239.

21. Stephen Oettermann, The Panorama: History of a Mass Medium (New York, 1997), 47.

22. This relates closely to the aesthetic famously put forward by Terry Eagleton in The Ideology of the Aesthetic (London, 1991), whose original cover featured Friedrich's Wanderer.

23. Crary, "Géricault, the Panorama, and Sites of Reality in the Early Nineteenth Century," 23.

24. Haladyn, "Friedrich's Wanderer: Paradox of the Modern Subject," 49.

25. Ibid., 58.

26. Koerner, Caspar David Friedrich and the Subject of Landscape, 182.

27. Bruno Latour reflects on the "global" implications of this assumption in Reset Modernity!, ed. Bruno Latour with Christophe Leclercq (Cambridge, MA, 2016), 91.

28. Gerhard Eimer, Caspar David Friedrich und die Gotik (Hamburg, 1965).

29. The Aesthetic and Miscellaneous Works of Friedrich von Schlegel, trans. E. J. Millington (London, 1900), 153. As quoted in Linda Siegel, Caspar David Friedrich and the Age of German Romanticism (Wellesley, 1978), 80.

30. Susan Crane argues that in the context of early nineteenth-century Germany, monuments served as "receptacles for the emotional overflow of historical consciousness"; Collecting and Historical Consciousness in Early Nineteenth-Century Germany (Ithaca, 2000), 35.

31. Andreas Huyssen, "Nostalgia for Ruins," Grey Room 23 (Spring 2006): 13.

32. Friedrich, "Äußerung bei Betrachtung einer Sammlung von Gemälden von größtenteils noch lebenden und unlängst verstorbenen Künstlern,” 115.

33. Heringman, "Deep Time," 60.

34. Martin Guntau, "The Rise of Geology as a Science in Germany around 1800," Geological Society London, Special Publications no. 317 (2009): 163-77.

35. Dietrich von Engelhardt, "Science, Society and Culture in the Romantic Naturforschung around 1800," in Nature and Society in Historical Context, ed. 
Mikulas Teich, Roy Porter, Bo Gustafsson (New York, 1997); Peter Hanns Reill, "The Legacy of the 'Scientific Revolution,'” in The Cambridge History of Science, ed. Roy Porter (New York, 2003), especially 4:42-43; Robert Richards, The Romantic Conception of Life: Science and Philosophy in the Age of Goethe (Chicago, 2002).

36. Rhoda Rappaport, When Geologists Were Historians, 1665-1750 (Ithaca, 1997); Martin Rudwick, Earth's Deep History: How It Was Discovered and Why It Matters (Chicago, 2014); Martin Rudwick, Bursting the Limits of Time: The Reconstruction of Geohistory in the Age of Revolution (Chicago, 2005); Rupke, "Caves, Fossils and the History of the Earth."

37. Mott Greene, Geology in the Nineteenth Century: Changing Views of a Changing World (Ithaca, 1982), 39. Stratigraphy has since become an influential concept in modern archaeology. As Whitney Davis has shown, it is also critical to art history and psychoanalysis insofar as it offers a way to conceptualize sequences of material, depictional, historical, and psychic accumulation. See Whitney Davis, Replications: Archaeology, Art History, Psychoanalysis (University Park, PA, 1996).

38. Martin Rudwick, "Minerals, Strata and Fossils," in Cultures of Natural History, ed. N. Jardine, J. A. Secord, and E. C. Spary (New York, 1996): 266-86. See also Rachel Laudan, From Mineralogy to Geology: The Foundation of a Science, 1650-1830 (Chicago, 1987), 104-5.

39. The literature on this is extensive, but two useful recent contributions are Peter Grupp, Faszination Berg: Die Geschichte des Alpinismus (Cologne, 2008), and Martin Scharge, Berg-Sucht: Eine Kulturgeschichte des frühen Alpinismus, 1750-1850 (Vienna, 2007). Although most accounts tend to assume that Alpinism emerged in the eighteenth century, it is clear that such aesthetic, religious, and scientific enthusiasm for mountains began much earlier. Martin Korenjak, "Why Mountains Matter: Early Modern Roots of a Modern Notion," Renaissance Quarterly 70 (2017): 179-219.

40. Amstutz, "Caspar David Friedrich and the Anatomy of Nature," 458.

41. Friedrich's reluctance to travel to Switzerland was probably motivated by his patriotic enthusiasm for German causes. Although some historians analyze Friedrich's work in relation to contemporaneous artistic and philosophical trends in France, they often overlook the fact that the artist vehemently refused to learn French-presumably for similar reasons.

42. See Aviva Burnstock, "The Materials and Technique of the Winter Landscape," National Gallery Technical Bulletin 24 (2003): 52-54.

43. Johann Wolfgang von Goethe, "On Granite," in Goethe's Collected Works, ed. and trans. Douglas Miller (New York, 1988), 12:133. For an analysis of the text see Elizabeth Powers, "The Sublime, 'Über den Granit,' and the Prehistory of Goethe's Science," Goethe Yearbook 15 (2008): 35-56.

44. Boime, A Social History of Modern Art, 608.

45. For an assessment of these two paintings, see Marie Bang, "Two Alpine Landscapes by C. D. Friedrich,” Burlington Magazine 107, no. 752 (November 1965): 571-75.

46. Mitchell, "Caspar David Friedrich's Der Watzmann," 461.

47. Friedrich, "Äußerung bei Betrachtung," 151-52.

48. Greene, Geology in the Nineteenth Century, 24-33.

49. Rudwick, Bursting the Limits of Time, 125.

50. John Playfair, "Bibliographical Account of the Late Dr James Hutton, F. R. S. Edin.," Transactions of the Royal Society of Edinburgh 5 (1805): 73.

51. Gould, Time's Arrow, Time's Cycle, 3. Gould's discussion of deep time was indebted to the slightly earlier work of John McPhee in Basin and Range (New York, 1981). 
52. Heringman, "Deep Time"; Rudwick, Bursting the Limits of Time and Earth's Deep History.

53. Heringman, Romantic Rocks, 12.

54. James Hutton, Abstract of a Dissertation... concerning the System of the Earth, its Duration and Stability ([Edinburgh], 1785).

55. James Hutton, Theory of the Earth (Edinburgh, 1795), as quoted in Edinburgh Review 69, no. 140 (July 1839): 449.

56. On Hutton's deductive method, see Greene, Geology in the Nineteenth Century, 24, and Rudwick, Bursting the Limits, 169.

57. Bruno Latour, Facing Gaia: Eight Lectures on the New Climatic Regime, trans. Catherine Porter (Medford, MA, 2017), 222.

58. Joseph Leo Koerner, "Caspar David Friedrich: Earth Life Art," in Reset Modernity!, 68-70.

59. On Hutton's "eternalism" and its religious valences, see Rudwick, Bursting the Limits, 169-72.

60. Ibid., 169.

61. In stating as much, I suggest that we wield the term "geological sublime" with greater caution. One particularly good example of how to deploy this increasingly popular term with historical dexterity is Paul White's "Darwin, Concepción, and the Geological Sublime," Science in Context 25, no. 1 (2012): 49-71.

62. Some have suggested that German Romantic naturphilosophie marks the origin point of present-day ecological thought. It's certainly true that Alexander von Humboldt was among those who began to articulate a more interactive and potentially destructive relationship between human activity and the environment in the early decades of the nineteenth century. For example, Dolores Martin Moruno, "Feeling Nature: Emotions and Ecology," Bellettino Filosofico 27 (2011-12): 247-61. Heather Sullivan, "Goethe's Colors: Revolutionary Optics and the Anthropocene," Eighteenth-Century Studies 51, no. 1 (2017): 115-24. On the French context see Greg Thomas, Art and Ecology in Nineteenth-Century France: The Landscapes of Théodore Rousseau (Princeton, 2000).

63. Writing about agency and the Anthropocene, Bruno Latour has argued that the human "subject" is not simply an agent that acts upon an object; the human subject is itself "subjected to" the acts of other agents. "To be a subject," he observes, "is not to act autonomously in front of an objective background, but to share agency with other subjects that have also lost their autonomy"; Bruno Latour, "Agency at the Time of the Anthropocene," New Literary History 45, no. 1 (Winter 2014), 5. For perhaps his most extended discussion of the significance of the nonhuman see Bruno Latour, The Politics of Nature: How to Bring the Sciences into Democracy, trans. Catherine Porter (Cambridge, 2004), an argument placed directly in relation to Romanticism in Timothy Morton, Ecology Without Nature: Rethinking Environmental Aesthetics (Cambridge, MA, 2007). The origin of this period, most commonly referred to as the Anthropocene, is contested, though many date it to the late eighteenth-century industrial revolution. See Heringman, "Deep Time," as well as Dipesh Chakrabarty, "The Climate of History: Four Theses," Critical Inquiry 35, no. 2 (2009): 197-222. Recently, several writers have debated the scope, causes, and proper terminology of this shift. For example, T. J. Demos, Against the Anthropocene (Berlin, 2017); Donna Haraway, "Anthropocene, Capitalocene, Plantationocene, Cthulucene: Making Kin," Environmental Humanities 6 (2015): 159-65; Jason Moore, ed., Anthropocene or Capitalocene? (Oakland, 2016). 